\title{
LATEST TECHNIQUE
}

\section{Endoscopic Septomucoplasty in Telangiectasia using Buccal Mucosa Graft: An Alternative Technique}

\author{
HUSAIN S, GENDEH BS
}

Department of Otorhinolaryngology-Head and Neck Surgery, Faculty of Medicine, Universiti Kebangsaan Malaysia Medical Centre, Jalan Yaacob Latif, Bandar Tun Razak, 56000 Cheras, Kuala Lumpur, Malaysia

\begin{abstract}
ABSTRAK
Salah satu tanda penyakit Hereditary Haemorrhagic Telangiectasia adalah pendarahan hidung. Kebanyakan pesakit mengalami pendarahan hidung yang sangat teruk sehingga memerlukan transfusi darah. Septodermoplasti adalah satu pembedahan yang sangat berkesan untuk merawat penyakit ini. Akan tetapi ianya menyebabkan kupingan dan lendir yang busuk di dalam hidung yang berpanjangan. Kami mencadangkan pembedahan septomucoplasti secara endoskopi menggunakan lapisan mukosa di dalam mulut sebagai teknik alternatif kepada septodermoplasti.
\end{abstract}

Kata kunci: HHT, pendarahan hidung, septodermoplasti

\section{ABSTRACT}

Epistaxis is one of the common presenting symptoms of patients with hereditary haemorrhagic telangiectasia (HHT). Majority of patients required blood transfusion due to intractable nasal bleeding. Septodermoplasty is an effective treatment for $\mathrm{HHT}$, however it gives rise to persistent nasal crusting and foul smelling nasal discharge post surgery. We present an endoscopic septomucoplasty using buccal mucosa graft as an alternative technique to septodermoplasty.

Keywords: $\quad \mathrm{HHT}$, epistaxis, septodermoplasty

Address for correspondence and reprint requests: Associate Professor Dr Salina Husain. Department of Otorhinolaryngology-Head \& Neck Surgery, Faculty of Medicine, Universiti Kebangsaan Malaysia Medical Centre, Jalan Yaacob Latif, Bandar Tun Razak, 56000 Cheras, Kuala Lumpur, Malaysia. Tel: +603-91456842 E-mail: drsalina_h@yahoo.com 
Hereditary

Haemorrhagic

Telangiectasia $(\mathrm{HHT})$ is also known as Rendu-Osler-Weber. Its prevalence is 1 in 5-8000 population (Shovlin et al. 2009). It is an autosomal dominant inheritance disorder characterized by mucocutaneous telangiectases, arteriovenous malformations and aneurysms. The diagnosis of $\mathrm{HHT}$ is made according to the Curacao criteria. There are four criteria established namely 1) Epistaxis 2) Multiple telangiectases on the lips, oral cavity, fingers and nose 3) Visceral lesions: Gastrointestinal telangiectasia (with or without bleeding), pulmonary arteriovenous malformation (AVM), hepatic AVM, cerebral AVM, spinal AVM 4) Family history of a first-degree relative. Epistaxis is the predominant symptom accounting for approximately 93\% of HHT patients. The bleeding arises from the telangiectatic spots on the nasal mucosa due to the inability of its blood vessels to retract or undergo vasospasm as the result of the absence of either muscular or elastic tissue layer in the vessel walls. The affluent areas of telangiectasias in the nose are anterior third of the septum, anterior tip of the inferior turbinates and the floor of the nose (Haitjema 1996). Almost 80-90\% of patients required multiple blood transfusions for intractable epistaxis. The severity of epistaxis worsened in later decades. Despite wide range of management offered, this disorder is particularly difficult to treat due to its tendency to recur and recalcitrant in nature. We present the endoscopic technique of septomucoplasty using buccal mucosa graft in conjunction with inferior turbinectomy. To our

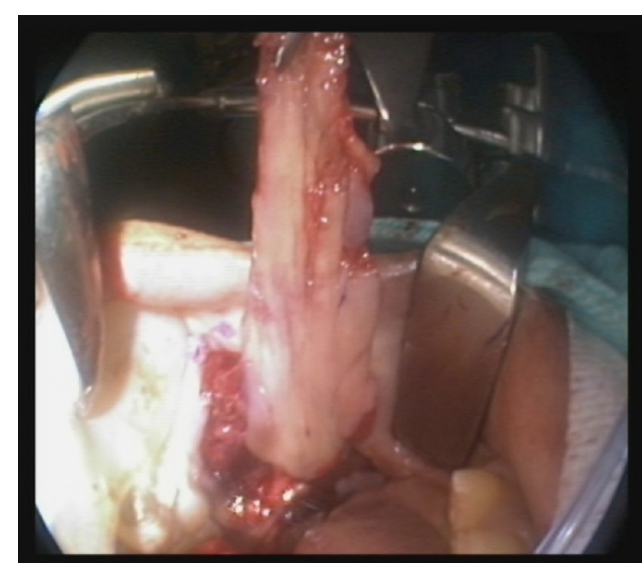

Figure 1: Picture showing the graft is harvested from the buccal mucosa.

understanding, this promising surgical procedure has been described only in few literature.

\section{SURGICAL TECHNIQUE}

The patient was oro-tracheally intubated. The left buccal mucosa was prepared. A Dingman intraoral retractor was applied to open the mouth and also used to stretch, lengthen and stabilize the buccal mucosa (Figure 1). Therefore, it provides an excellent access to the donor site. The area measuring approximately $3.5 \times 4.0 \mathrm{~cm}$ was marked for graft harvesting. Injury to the Stensen's duct can be avoided by locating its landmark which is reliably at the level of the upper second molar. A local anaesthesia consisting of $1 \%$ lidocaine with adrenaline (1: 100,000) was injected submucosally along the edges of the graft site to provide hemostasis. The graft was dissected using scalpel and non-mucosal tissue was removed to enhance its potential for revascularization. The donor site was then closed with 


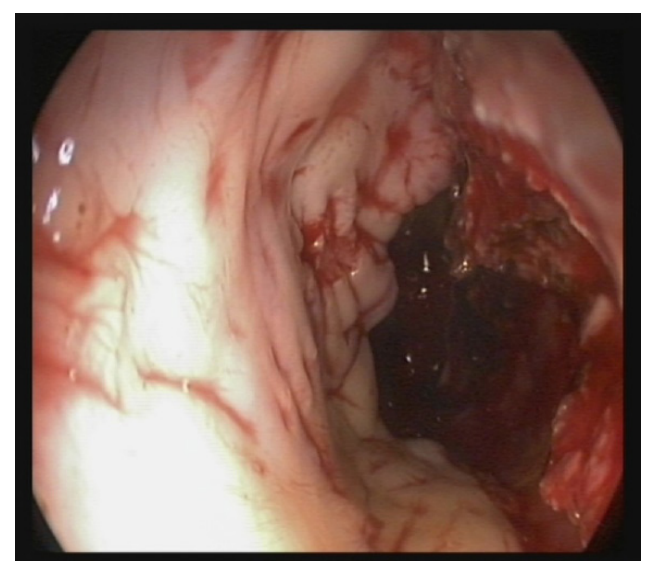

Figure 2: Buccal mucosal graft lining the left nasal cavity

an interrupted absorbable suture (Figure 2). The mucosa of the left nasal septum, floor of the nose and inferior turbinate was injected with $1 \%$ lidocaine with adrenaline (1:100,000). A sphenopalatine artery block was performed. The incision was made along the mucoepidermal junction on the septum and floor of the nose measuring about $3 \mathrm{~cm}$. The mucosa of the septum and floor of the nose was removed using a microdebrider blade size $2.9 \mathrm{~mm}$. The mucoperichondrium of the septum was left intact to provide raw area for the graft. The bleeding was controlled by ribbon gauze soaked in adrenaline (1:1000) packing. Inferior turbinectomy was performed. The buccal mucosa graft was placed onto the raw area of left nasal septum using bayonet forceps. Bioglue was used to approximate the edges of the graft to the nasal mucosa and packed with neuropatties soaked in gentamicin. The pack was removed on the fifth day post-surgery. At oneyear follow-up, patient had intermittent epistaxis, which does not require blood transfusion.

The management of epistaxis associated with HHT is challenging. To date, there is no definitive treatment modality that has been proved to be the gold standard of management of HHT transfusion-dependent epistaxis. This condition is essentially difficult to treat due to its tendency to recur and recalcitrant in nature. Various medical and surgical therapies have been applied in the management of epistaxis dependent HHT patients such as septodermoplasty, Modified Young's procedure, resurfacing the nasomaxillary cavity, use of the microdebrider, bipolar cautery, $\mathrm{Nd}$ YAG laser photocoagulation, contact endoscopy, nasal obturator, officebased pulsed dye laser treatment, septodermoplasty and potassiumtitanylphosphate (KTP) laser therapy (Harvey et al. 2008, Lund et al. 2017)

Evidence suggested septodermoplasty remains the effective treatment of transfusion dependent epistaxis in patients with HHT (Harvey et al. 2008). However, desquamation of skin graft giving rise prolonged nasal crusting and foul smelling nasal discharge post surgery. Following that septodermoplasty using buccal mucosal grafts was introduced and obtained an excellent result. Buccal mucosa is lined by nonkeratinizing squamous cell epithelium and a thin lamina propria, which is rich in capillaries relative to that of skin. The potential surface area of graft that can be harvested from one side is approximately up to $16.5 \mathrm{~cm}^{2}(3 \times 5.5$ cm) (Eppley et al. 1997). Buccal mucosa graft is a reliable and easily accessible 
source of graft material. It eliminates the complications associated with skin by providing better histological composite, hidden donor site and multiple grafts can be harvested at the similar donor site due to its excellent epithelial tissue regeneration. Subjects were asymptomatic of persistent postoperative nasal crusting and odour. Additionally, they were free from epistaxis twice as long as for standard septodermoplasty using splitthickness skin grafts. This finding was observed in our case as well. The foul smelling nasal discharge and crusting were markedly reduced. However, patient developed bleeding from the anterior superior part of the grafted site, which was cauterized successfully in the clinic. It is possible to have bleeding post septodermoplasty, it can arise from the anterosuperior portion of the septal mucosa which was left uncovered at the suture margin (Keiichi et al. 2006)

\section{CONCLUSION}

Septomucoplasty using buccal mucosa graft is an alternative technique to overcome the problems associated with split thickness skin graft.

\section{REFERENCES}

Eppley, B.L., Keating, M., Rink, R.. 1997. A Buccal Mucosal Harvesting Technique for Urethral Reconstruction. J Uro/ 57(4): 1268-70.

Haitjema, T., Westermann, C.J., Overtoom, T.T., Timmer, R., Disch, F., Mauser, H., Lammers, J.W. 1996. Hereditary hemorrhagic telangiectasia (Osler-Weber-Rendu disease): new insights in pathogenesis, complications, and treatment. Arch Intern Med 156: 714-9.

Harvey, R.J., Kanagalingam, J., Lund, V.J. 2008. The impact of septodermoplasty and potassiumtitanylphosphate (KTP) laser therapy in the treatment of hereditary hemorrhagic telangiectasia-related epistaxis. Am / Rhino/ 22: 182-7.

Keiichi, I., Hidetaka, T., Yoshinori, Y., Kenichi, N. 2006. Nasal dermoplasty for Japanese hereditary hemorrhagic telangiectasia. Auris Nasus Larynx 33: 423-8.

Lund, V.J., Darby, Y., Rimmer, J., Amin, M., Husain, S. 2017. Nasal closure for severe hereditary haemorrhagic telangiectasia in 100 patients. The Lund modification of the Young's procedure: a 22-year experience. Rhinology 55(2): 135-41.

Shovlin, C.L., Guttmacher, A.E., Buscarini, E., Faughnan, M.E., Hyland, R.H., Westermann, C.J., Kjeldsen, A.D., Plauchu, H. 2000. Diagnostic criteria for hereditary hemorrhagic telangiectasia (Rendu-Osler-Weber syndrome). Am J Med Genet 91: 66-7. 